\title{
Az ösztrogénmetabolom biológiai és klinikai jelentősége lokális folyamatokban
}

\author{
Kovács Krisztián ${ }^{1,2}$. Vásárhelyi Barna dr. ${ }^{1,2}$. Mészáros Katalin $\mathbf{d r} .^{3}$ \\ Patócs Attila dr. ${ }^{1,2,3}$. Karvaly Gellért dr., ${ }^{1,2}$ \\ 'Semmelweis Egyetem, Általános Orvostudományi Kar, Laboratóriumi Medicina Intézet, Budapest \\ ${ }^{2}$ Bionika Innovációs Központ Nonprofit Kft., Budapest \\ ${ }^{3}$ MTA-SE Lendület Örökletes Endokrin Daganatok Kutatócsoport, Budapest
}

\begin{abstract}
Az ösztrogénhormonok fiziológiai szerepe sok tekintetben ismert. Meglehetősen kevés információ áll azonban rendelkezésre az ösztron és az ösztradiol lebontása során képződő vegyületek szerepéről a különböző, ösztrogénhatással összefüggésbe hozott kórképekben. A kutatások intenzív érdeklődésének középpontjában jelenleg a két ösztrogénhormon mellett tizenhárom extragonadális metabolit áll. A képződő metabolitok protektív vagy éppen proinflammatorikus és/vagy proonkogén hatással rendelkeznek. A szisztémás keringésben mért metabolitszintek nem mutatnak összefüggést a lokálisan megjelenő metabolitokéval, ennek a jövőben diagnosztikai jelentősége lehet. A jelen tanulmány célja a perifériás szövetekben az extragonadális metabolommal kapcsolatos irodalmi források átfogó áttekintése, valamint felhívni a figyelmet a perifériás szövetek ösztrogénhomeosztázisának szerepére, az ösztrogénmetabolom igazolt, valamint a klasszikus hormonhatásoktól eltérő biológiai aktivitására, egyes kórfolyamatokban azonosított klinikai jelentőségére. Ezek az ismeretek a lokálisan determinált kórfolyamatok megértését, korai diagnosztikáját a későbbiekben a metabolomika eszköztárával jelentősen segíthetik.
\end{abstract}

Orv Hetil. 2017; 158(24): 929-937.

Kulcsszavak: ösztrogénmetabolom, perifériás szövetek, emlőkarcinóma, HPLC-MS/MS

\section{The biological and clinical relevance of estrogen metabolome}

Considerable knowledge has been gathered on the physiological role of estrogens. However, fairly little information is available on the role of compounds produced in the breakdown process of estrone and estradiol wich may play a role in various diseases associated with estrogen impact. To date, approximately 15 extragonadal estrogen-related compounds have been identified. These metabolites may exert protective, or, instead, pro-inflammatory and/or prooncogenic activity in a tissue-specific manner. Systemic and local estrogen metabolite levels are not necesserily correlated, which may promote the diagnostic significance of the locally produced estrogen metabolites in the future. The aim of the present study is a bibliographic review of the extragonadal metabolome in peripheral tissues, and to highlight the role of the peripheral tissue homeostasis of estrogens as well as the non-hormonal biological activity and clinical significance of the estrogen metabolome.

Keywords: estrogen metabolome, periferal tissues, breast cancer, HPLC-MS/MS

Kovács K, Vásárhelyi B, Mészáros K, Patócs A, Karvaly G. [The biological and clinical relevance of estrogen metabolome]. Orv Hetil. 2017; 158(24): 929-937.

(Beérkezett: 2017. április 7.; elfogadva: 2017. április 27.)

\section{Rövidítések}

2-MeEl = 2-metoxi-ösztron; 2-MeE2 = 2-metoxi-ösztradiol; 2 -OHEl $=2$-hidroxi-ösztron; 2 -OHE2 $=2$-hidroxi-ösztradiol; 4-OHE1 = 4-hidroxi-ösztron; 4-OHE2 = 4-hidroxi-ösztra- diol; 16-KE2 = 16-keto-ösztradiol; 16-OHE1 = 16-hidroxiösztron; 16-OHE2 = 16-hidroxi-ösztradiol; 17-epiE3 = 17-epi-ösztriol; 17ß-HSD = 17ß-szteroid-dehidrogenáz; $\mathrm{COMT}=$ katechol-O-metil-transzferáz; $\mathrm{COPD}=$ krónikus 
obstruktív tüdőbetegség; CYP19 = aromatázenzim; DHEA = dehidroepiandroszteron; DHT = dihidrotesztoszteron; El = ösztron; E2 = ösztradiol; E3 = ösztriol; ER = ösztrogénreceptor; EST = ösztrogén-szulfotranszferáz; FSH = folliculusstimuláló hormon; GPER = G-fehérjével kapcsolt ösztrogénreceptor; $\mathrm{GSH}=$ glutation; GST = glutation-S-transzferáz; HPLC-MS/MS = nagy hatékonyságú folyadékkromatográffal kapcsolt tömegspektrometria; IC50 = félhatásos gátlókoncentráció; $\mathrm{LH}=$ luteinizáló hormon; $\mathrm{NQOl}=\mathrm{NAD}(\mathrm{P}) \mathrm{H}$-kinondehidrogenáz; RA = rheumatoid arthritis; SERM = szelektív ösztrogénreceptor-modulátor; SLE = szisztémás lupus erythematosus; $\mathrm{SM}=$ sclerosis multiplex; SS = szteroid-szulfatáz; SULT $=$ szulfotranszferáz; TNF- $\alpha=$ tumornekrózis-faktor-alfa; UDP-UGT = uridin-5' -difoszfo-glukuronozil-transzferáz

Az ösztrogénvegyületek szerteágazó és kiemelkedő jelentőséggel bíró biológiai aktivitással rendelkeznek. Klasszikus hormonhatásaik mellett jelentősen befolyásolják az immunrendszer múködését és a csontanyagcserét, fontos szerepük van számos központi idegrendszeri folyamatban, továbbá a legfontosabb, nóket érintő malignus állapotok (emlőrák, petefészekrák) és több, szintén elsősorban nőket érintő autoimmun betegség (például rheumatoid arthritis, szisztémás lupus erythematosus, Crohn-betegség) kialakulásában. Az ösztrogéneknek további fontos szerep jut a szív- és érrendszeri megbetegedések, valamint a myo- és endometrium, a hüvelyhám és az alsó urothel kóros állapotainak kialakulásában. A különböző folyamatok szabályozottsága mögött az ösztrogénhormonok keletkezésének és metabolizmusának lokálisan modulált rendszere rejlik. Ez a rendszer egészében még nem ismert, azonban az ösztrogénmetabolommal kapcsolatos jelenlegi tudásunk lehetővé teszik az alapvető mozgatórugók megértését, terápiás célok és a klinikai diagnosztikában történő alkalmazáshoz szükséges vizsgálati irányok azonosítását.

A CYP19 enzim és a 17HSD ösztrogén termékei, az E1 és az E2 metabolizmusa során számos további vegyület keletkezik. Ezek közül csak egy az E3, emellett azon-

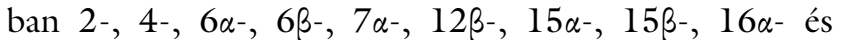
$16 \beta$-hidroxiláció útján, valamint epimerizációval is keletkeznek termékek $[1,2]$. E vegyületeknek hormonális, immunrendszeri múködést, anyagcserét és malignus folyamatokat moduláló hatása van, amit alátámaszt, hogy az autoimmun betegségek előfordulási gyakorisága nemi preferenciát mutat, illetve, hogy a nók életciklusának különböző pontjain az ösztrogénháztartás a különböző szövetekben változik $[3,4]$.

\section{A gonadális-extragonadális ösztrogénháztartás eltérései}

A gonádokban és az extragonadálisan keletkező ösztrogének szintézise és metabolizmusa nem parallel történik [5-7].

Az ovariumban az ösztrogének szintézise az androgénekkel együtt a téka-sejtekben kezdődik és a granulosasejtekben az androgéneknek az aromatázenzim által ösztrogénekké történő átalakításával fejeződik be. A lokálisan képződött ösztrogének stimulálják a granulosasejtek proliferációját és parakrin/autokrin módon elösegítik az FSH és az LH hatásait. Az ösztradiol egyik legfontosabb hatása, hogy fokozza az FSH-indukált aromatázexpressziót az ovariumban $[7,8]$. A szintézisben szerepet játszik számos $17 \beta$-szteroid-dehidrogenáz izoenzim is [9].

A petefészekben keletkező ösztrogénvegyületek átalakulása nagyobbrészt a májban, kisebb mértékben a vesében megy végbe, I. és II. fázisú reakciók során (1. ábra).

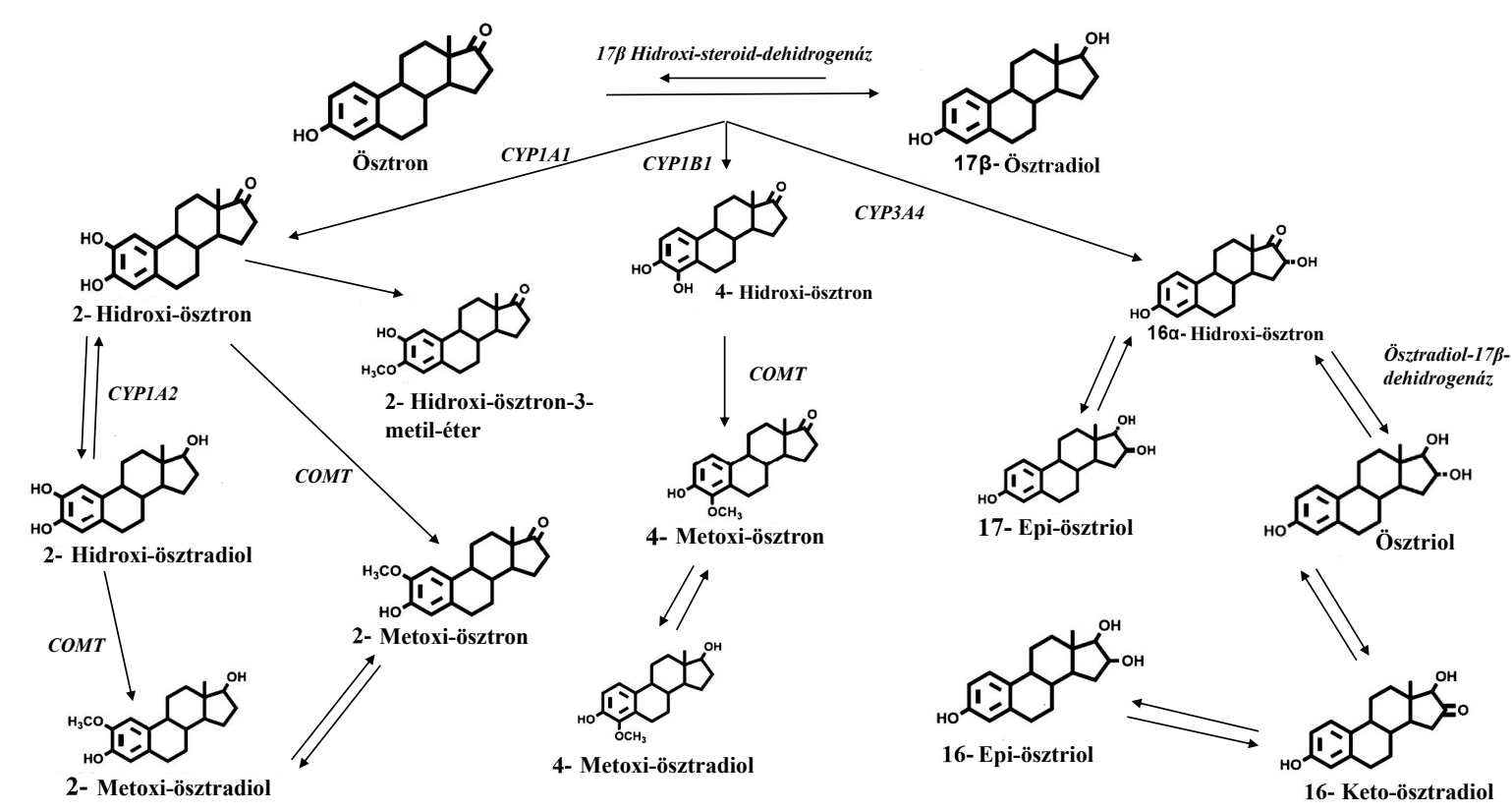

1. ábra |Az ösztrogénmetabolizmus folyamata az eddig feltérképezett, metabolizmusban részt vevő enzimekkel 


\section{Ösztradiol}

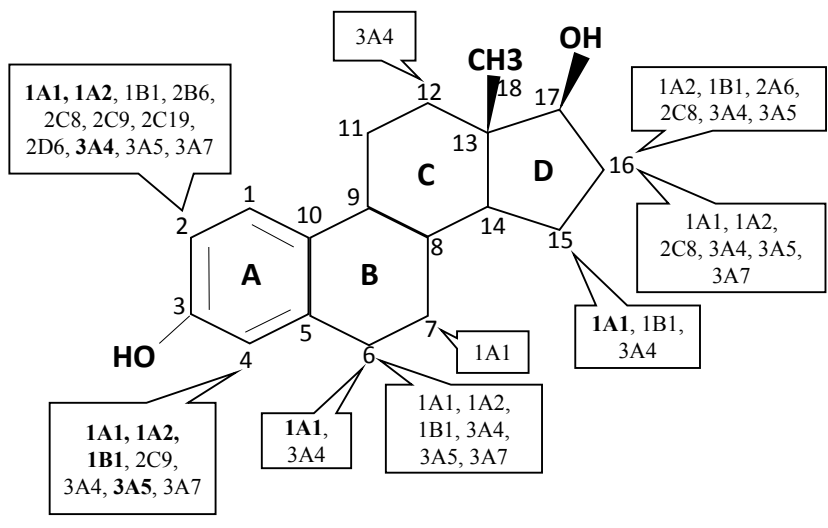

\section{Ösztron}

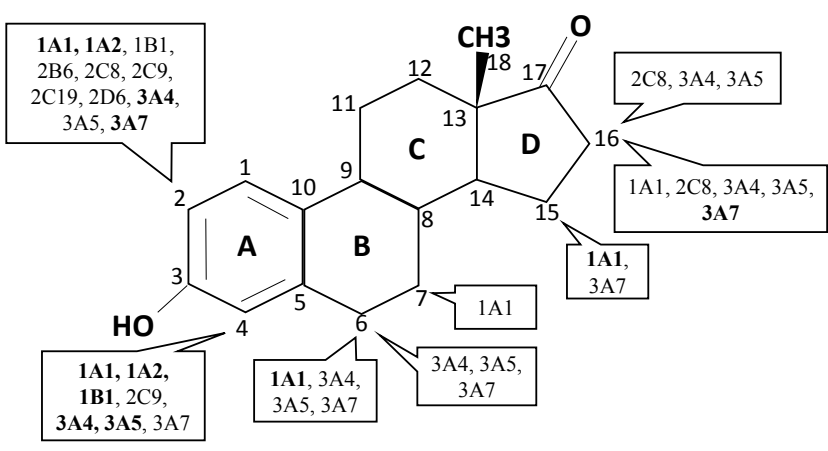

2. ábra

| Ösztradiol, ösztron CYP-enzimei

Az I. fázisú, minden esetben oxidációt jelentő átalakítást mintegy 15 különböző CYP-izoenzim végzi [10]. Ezek közül a legjelentősebb a máj P450-aktivitásának 1015\%-át kitevő CYPlA2, amely elsősorban a 2-es, jóval kisebb mértékben a 4-es pozícióban történő hidroxilációt katalizálja $[1,11]$. Emellett számos egyéb, a CYPl-, CYP2- és CYP3-csoportokba tartozó enzim aktivitását igazolták (2. ábra). A fó metabolitok a 2-hidroxi-ösztradiol és a 2-hidroxi-ösztron, amelyek mellett jóval kisebb mennyiségben, fóleg a 4-es és 16-os pozícióban hidroxilált termékek képződnek. Az ösztron és az ösztradiol hidroxilációja kinetikailag nem azonos, az E2 átalakítása 2-hidroxi-ösztradiollá lényegesen nagyobb sebességgel történik, mint az El átalakítása 2-hidroxi-ösztronná. A II. fázisú reakciókat SULT, UDP-UGT, NQOI, GST és a COMT mediálják, szulfát-, glükuronid- és metilezettglutation-konjugátumokat eredményezve. Ezekben az átalakulásokban az anyavegyületek és a hidroxilcsoportot tartalmazó metabolitok egyaránt részt vesznek. A szulfatálás elsősorban a 3 -as pozícióban, a glükuronidálás pedig a 3-as és - az E2 esetében elsődlegesen, más ösztrogénvegyületek esetében változó mértékben - a 17-es pozícióban lévő hidroxilcsoporton megy végbe [12]. A 2-es és 4-es pozícióban hidroxilált formák amelyeket összefoglalóan a szakirodalom katecholösztrogénként említ - a COMT szubsztrátjaiként emellett 2-metoxi- és 4-metoxi-ösztrogénekké alakulnak, a 2-hidroxi-vegyületekből pedig 2-hidroxi-3-metoxi-termékek is képződnek [13]. A konjugáció a szisztémás keringésbe kerülő E1, E2 és az egyes metabolitok nagy hányadát érinti, de ezeknek csak kis részük található meg szabad formában [11].

Közvetlen és közvetett bizonyítékok igazolják, hogy számos perifériás szövet, továbbá az agy több régiójának élettani múködését befolyásolja az ösztrogén és annak metabolitjai. Az extragonadális ösztrogének szintézise emellett szövetenként eltérő és összetett reguláció alatt áll [14]. Közvetlen adatok igazolják, hogy menarche előtt és a posztmenopauza idején is folyamatos és jelentős ösztrogéntermelés zajlik a zsírszövetben, az emlöben, a vesében és a bőrben [15]. Az ösztrogénhatást közvetítő ER $\alpha$ és ER $\beta$ ösztrogénreceptorok jelenlétét kimutatták számos perifériás szervben; az ER $\alpha$-t a csontban és a májban, míg az ER $\beta$-t a vastagbélben, a csontvelőben, a vascularis endothelben, a tüdőben, a hólyagban és az agyban [15]. A kulcsfontosságú aromatázenzim jelenlétét az agy számos területén és az osteoblastokban is igazolták $[8,16]$.

$\mathrm{Az}$ extrahepaticus fázis I metabolizmus során számos, CYP-izoenzimek (1A1, 1A2, 3A, 1B1) által katalizált oxidációs folyamat megy végbe. A CYPlA2 és CYP3A4 izoenzimekkel szemben a CYPlAl és a CYPlBl expressziója a májszövetben elhanyagolható $[2,17]$. Mindkettő konstitutív módon expresszálódik a különböző perifériás szövetekben, ugyanakkor a CYPlAl induktív expresszióját figyelték meg prosztatában $[18,19]$. A CYP-izoformák strukturálisan és funkcionálisan is homológiát mutatnak egymással, ezért szelektív gátlásuk bonyolult [20]. A CYPlAl elsősorban a 2-hidroxiösztradiol-termelést katalizálja, és kisebb mennyiségben állít elő 2-hidroxi-ösztront, míg a CYPlA2 enzim esetében ez fordított képet mutat. Az egyes CYPl izoenzimek 2-es és 4-es pozícióban lévő szénatomok hidroxilációjával kapcsolatos szelektivitása szintén különbözik, aminek a kórfolyamatok kialakulása szempontjából alapvető jelentősége van. A CYPIAl esetében a hidroxiláció elsősorban a C2 szénatomon játszódik le és protektív metabolitokat eredményez, míg a CYPlBl esetében a 4-hidroxi-útvonal jelentősen preferált, olyan termékek keletkezéséhez vezetve, amelyeknek a malignus és autoimmun folyamatok kialakulásában kulcsszerepe van [1]. A CYPIBl túltermelódik különböző tumorokban, azonban a tumorigenezisben betöltött szerepéért az is felelős, hogy aktivál olyan karcinogén kémiai anyagokat, mint a heterociklusos aminok, aromás aminok vagy a policiklusos aromás szénhidrogének [21].

A fázis II reakciók az ösztrogének esetében szöveti szintű detoxikációs útvonalat és tárolási lehetőséget egyaránt jelentenek. Ezek magukban foglalják a szulfatálást, a metilációt és a GSH-val történő konjugátumképzést. A katecholösztrogének metilációját a COMT katalizálja, valamint az ösztrogén-szemikinonok és kinonok glutationnal is reakcióba lépnek. A katalízis során a ka- 
techolösztrogének kinonokká, protektív 2-metoxi-formává alakulása is megtörténik.

Egyes zöldségek (kiemelten a szója), gyümölcsök, természetgyógyászati termékek és gyógyszerek komponensei ösztrogénszerű hatásokkal rendelkeznek, mások az endogén ösztrogénvegyületek metabolizmusát befolyásolják. Sok fitoösztrogén-tartalmú természetgyógyászati terméket forgalmaznak kifejezetten hormonpótlási javallattal, jótékony hatásaik mellett azonban ezek egyben endokrin diszruptorok is [22]. A leggyakrabban fogyasztott gyümölcsökben is megtalálható stilbének és flavonoidok egyúttal a CYPlAl, CYPlA2 és CYPlBl enzimek kompetitív inhibitorai, akárcsak a citrusfélék által termelt furokumarinok, számos alkaloid, valamint a marihuána fó hatóanyagai, a kannabidiol és a kannabinol [20]. A hagyományos indiai és kínai orvosláson alapuló termékekben szintén előforduló antrakinonok és naftokinonok a CYPlAl-et és CYPlA2-t, szerkezettől függően, kompetitív vagy nem kompetitív módon blokkolják, ezek között különösen markáns hatással (IC50: 0,40 $\mu \mathrm{mol} / \mathrm{l}$, illetve $0,53 \mu \mathrm{mol} / 1$ a CYPlAl-re és a CYPlA2-re vonatkozóan) rendelkezik a 4-amino-1-klór-3-metil-antrakinon $[20,23]$.

A szintetikus gyógyszerek közül CYPlA1, CYP1A2, illetve CYP1Bl inhibitorként hat például a $17 \alpha$-etinilösztradiol, a fluvoxamin, a lidokain, a mexiletin, a mikonazol, a takrin és a zileuton [20]. Az ekvileninösztrogéneket tartalmazó készítményekben található ekvilenin reaktívkatechol-metabolitja a 4-hidroxi-ekvilenin, amely gátolja a detoxifikáló enzimek, például a GST vagy a COMT múködését, így az ösztrogénmetabolizmust is befolyásolja [19, 20, 24].

Az ösztrogénhomeosztázist szintén jelentősen befolyásoló SERM-mel kapcsolatos ismeretekre itt nem térünk ki, ezeket $A n$ közleményében részletesen bemutatja [25].

\section{Az ösztrogénmetabolitok biológiai hatásai}

Az ösztrogénmetabolitok pontos szerepe a különböző celluláris és szöveti folyamatokban egyelőre részben tisztázott, a jelenlegi ismeretek azonban következetesen arra mutatnak rá, hogy számos ösztrogéndependens kórfolyamatban a lokális bioszintézis során keletkező és szintén lokálisan átalakuló ösztrogénvegyületek szerepét kell keresni $[3,26]$. Az egyes lebontási útvonalak metabolitjainak eltérő szerepük van a hormondependens betegségek kialakulásában [27].

A lokális ösztrogénmetabolizmus markánsan különbözik a hepaticus folyamatoktól és szöveti szelektivitást mutat [26]. A nem hormonális hatások esetében intrakrin, autokrin és parakrin folyamatokról van szó, az ösztrogénvegyületekhez köthető súlyos kórállapotok jelentős része nem a szisztémás keringésből származó molekulákkal van összefüggésben [28]. A metabolizmusra in situ kerül sor [8].

A markáns szöveti CYPlBl-expresszió miatt a perifériás metabolizmus elsődleges termékei a 4-hidroxi-meta- bolitok (4-hidroxi-ösztradiol és 4-hidroxi-ösztron), amelyek mutagén, karcinogén tulajdonságát igazolták [29]. Ezek ártalmatlanítását szintén lokális enzimek végzik, így nagy jelentősége van a szöveti COMT-aktivitásnak e katecholösztrogének inaktív metiléterekké történő átalakítása révén [30]. A hypoxiás mikrokörnyezet szintén a 4-hidroxi-metabolitok képződésének kedvez [31]. Az egyes ösztrogénhormonok és metabolitok mennyisége tehát abszolút értelemben és arányaiban is szövet- és állapotfüggő $[32,33]$.

A 4-hidroxi- (és kisebb mértékben a 16-hidroxi-) ösztrogének továbbalakulásával keletkező kinonok instabil vegyületeket képeznek a DNS-adenin és -guanin residuumaival, ami depurinálódáshoz, mutációkhoz vezet. Az ösztrogénkinonok redukciója során továbbá reaktívoxigén-gyökök képződnek, amelyek a DNS-t közvetlenül károsítják, emellett a prekurzor katecholösztrogének újratermelődnek. Végül a 4-hidroxi-ösztrogének az ösztrogénreceptorokhoz kapcsolódva aktiválják az ER mediálta jelátviteli útvonalakat, ezzel iniciálva a DNS-károsító mechanizmusokat. Mivel az egyes folyamatok a szöveti mikrotérben, igen kis mennyiségü vegyület részvételével játszódnak le, a szisztémás ösztradiolszintek mérése az ösztrogénhatással összefüggő kórfolyamatok korai diagnózisában és monitorozásában nem elégséges [34].

Más ösztrogénmetabolitoknak jótékony hatásai vannak. A menopauza előtt nagyrészt szisztémásan, de a perifériás szöveteken és az agyban is termelődő 2-hidroxiösztrogének hormonális aktivitása sokkal gyengébb, ugyanakkor a tumorsejtek proliferációját és az angiogenezist gátolják (3. ábra) [35]. A 2-hidroxi-ösztrogének kialakításáért a CYPlAl enzim a felelős, ezek az ER-hez nem kötődnek, ezáltal kevésbé reaktívak [36, 37]. Jelenleg is több klinikai vizsgálat zajlik, ahol a 2-metoxiösztradiol antiangiogenetikus, valamint antivascularisatiós hatását értékelik [38].

\section{Az ösztrogénmetabolom szerepe az emlőkarcinómában}

Ösztrogéndependens tumorszövetekben szisztémás prekurzorként az androgén szteroidhormonok, elsősorban az androsztendion, a tesztoszteron és a dehidroepiand-

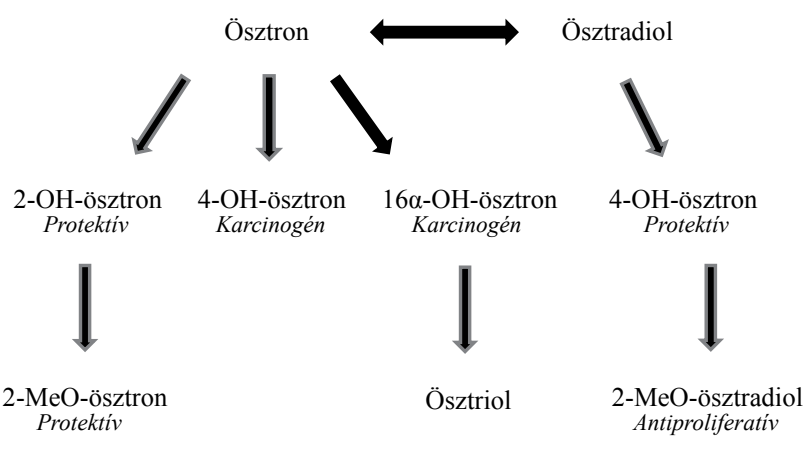

3. ábra $\quad$ A protektív, karcinogén és antiproliferatív ösztrogénmetabolitok 
roszteron jelennek meg, amelyek lokálisan alakulnak tovább ösztrogénekké. A szintézisben az aromatáz mellett $17 \beta$-hidroxi-szteroid-dehidrogenázok is részt vesznek, és ezek expressziója eltér a női gonád szövetekben megfigyelttől [9]. Emlőkarcinóma-sejtekben a 17HSDl- és a 17HSD2-expresszió egymással és az ER-expresszióval szoros összefüggést mutat [14]. Az androgénprekurzorokból elsősorban El keletkezik, amely számos szövetben szulfátkonjugátumként tárolódik, és a biológiailag sokkal aktívabb E2 elsődleges forrásaként van jelen. A 17HSD1 és a 17HSD2 az E1-E2 átalakulást katalizálja, míg más izoenzimek, például a 17HSD8 az E2 oxidációját segítik elő $[5,6,39]$.

Az aktív ösztrogénformák metabolizmusa elnyújtott ösztrogénhatást eredményez az emlőszövetben. A konjugációs enzimek koncentrációja ezekben a szövetekben alacsony, ami az aktív konjugálatlan metabolitok (E1, E2, E3, 2-, 4-, 16-hidroxi-ösztrogének, 16-, 17-epimerek) felszaporodását eredményezi. Bizonyítást nyert, hogy a 2-hidroxi-ösztron, a 3-metil-éter és a 2-metoxiösztradiol megemelkedett koncentrációja nem szignifikánsan ugyan, de csökkentheti az emlőrák rizikóját, ugyanakkor a megemelkedett szabad ösztron koncentrációja magasabb kockázatot jelent [40]. Az emelkedett 2-hidroxi-ösztron-szint csökkenti az emlőkarcinóma kialakulásának esélyét, ugyanakkor megnövelheti az osteoporosis kockázatát. Ellentétes a hatása a 16-alfa-hidroxiösztronnak, egyes kutatók szerint magasabb szintje pozitív korrelációt mutat az emlőrák rizikójával, míg az osteoporosis kockázatát csökkentheti [41], mások ezt kétségbe vonták [42]. Posztmenopauzában az ösztrogénprodukció állandó és a perifériás szövetekre lokalizálódik, így az emlőszövet is folyamatos ösztrogénhatásnak van kitéve.

Premenopauzában és posztmenopauzában az ösztrogénvegyületek mennyiségi arányai eltérőek. 110, premenopauzában lévő nő vizeletéból 15 ösztrogén és ösztrogénmetabolit szintjét LC-MS/MS módszerrel vizsgálták. Az ösztradiol, az ösztron és metabolitjaik mennyiségei között gyenge korrelációt találtak. A 2-es és a 4-es hidroxilációs útvonal termékei ezzel szemben nagyon szoros korrelációt mutattak az ösztrogénhormonok szintjeivel [43].

\section{Az ösztrogénmetabolitok autoimmun betegségekre kifejtett hatásai}

Az ösztrogénmetabolitok szisztémás gyulladásos folyamatokban betöltött szerepét korábban bizonyították [44]. Az ösztrogénhormonok ezzel összhangban valószínúleg kulcsszerepet játszanak az autoimmun kórképek, például az RA, az SLE vagy az SM kialakulásában, ami a nők kiemelt érintettségében mutatkozik meg $[4,45]$.

Synoviocytákban elsősorban DHEA-ból keletkezik nagy mennyiségü E1, E2 és E3; ebben a sejttípusban az androsztendion és a tesztoszteron az aromatázenzim múködését blokkolja [46]. Autoimmun betegségekben a gonadális szteroidok szérumszintje csökken. Az RA során kialakuló synovitisben a gyulladásos citokinek szintje megemelkedik (TNF- $\alpha$, IL-1, IL-6), ezek stimulálni képesek a helyi aromatázaktivitást, ami pedig az ösztradiol/ösztron arány eltolódását eredményezi. Ehhez hozzájárul a 17ß-hidroxi-szteroid-dehidrogenázok megnövekedett aktivitása [47] (4. ábra). A fentieket igazolja, hogy az E2 szintje többszörösére emelkedik rheumatoid arthritisben szenvedő betegek synovialis folyadékában [48].

Capellino és mtsai RA-betegek esetében a hidroxiösztrogén-metabolitok hatását vizsgálták humán monocyták aktivációjára, ezáltal az ízületi gyulladások, foóként az RA kialakulására. THPl típusú humán monocytasejtvonalat kezeltek különböző dózisú ösztrogénmetabolit-vegyületekkel (16-OHE1, 16-OHE2, 4-OHE1, 4-OHE2, 2-OHE1, 2-OHE2). A 4-OHE1 és a 2-OHEl alacsony koncentrációban szignifikánsan serkentette a sejtproliferációt, míg magas dózisban csökkentette azt. Ellentétes hatását találták a 16-OHE2- és a 4-OHE2metabolitoknak. Az ösztrogénmetabolitok modulálhatják a synoviumsejteket, így szerepet játszhatnak a lokális gyulladásos mechanizmusok kialakulásában [49]. Ugyancsak RA-ban vizsgálva a 2-MeOE2, a 2-OHE1, a 2-OHE2 és a 4-OHE2 gátolta a TNF- $\alpha$ szekrécióját, míg a 16-hidroxi-formáknak nem volt befolyása a citokinprodukcióra $[33,50,51]$. A megemelkedett ösztrogén/androgén arány a proinflammatorikus 16-hidroxiformák szintézisét segíti elő [50]. A 16 $16 \mathrm{OH}-\mathrm{El}$ az ösztrogénreceptor-fehérjével kovalens és másodlagos kötést egyaránt teremt. A komplex főként a nukleáris mátrixra lokalizálódik, és ott részt vesz az ösztrogénreceptor mediálta malignus folyamatokban [52]. Pellino és mtsai kapcsolatot találtak az autoimmun kórképek és a malignus folyamatok kialakulása között: Crohn-betegségben szenvedő nőket és nőnemú rokonaikat vizsgálva pozitív korrelációt találtak az emlőkarcinóma kialakulásának esélyével [53]. Tian és mtsai nem mutattak ki meg-

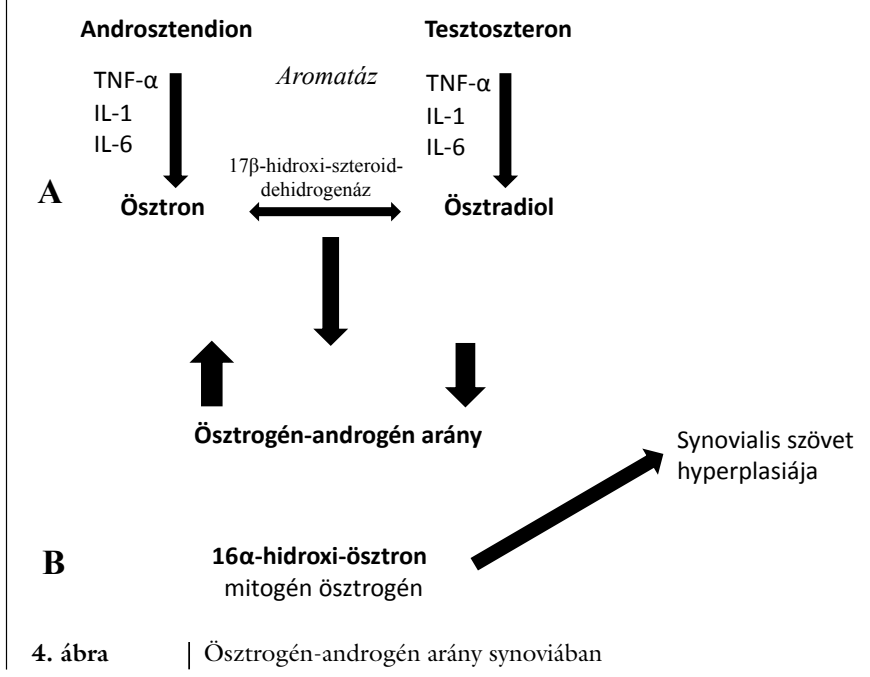


növekedett esélyt emlőkarcinóma kialakulására RA-s betegeknél [54]. Mások a sclerosis multiplex és az emlőrák kapcsolatát vizsgálva szintén gyenge korrelációt találtak [55].

\section{A prosztata betegségeinek kapcsolata az ösztrogénmetabolizmussal}

A prosztata megbetegedéseinek klinikai diagnosztikájában kulcsfontosságú szerep jut az androgén szteroidhormonoknak („androgénhipotézis”) [56]. Az androgénhormonok, elsősorban a tesztoszteron és az $5 \alpha$-reduktáz által végzett átalakítása során keletkező DHT vitális paraméterei a prosztatakarcinóma és a jóindulatú prosztata-hyperplasia kialakulásának $[56,57]$. A prosztata aromatázenzim-termelése megváltozik malignus folyamatokban, ami az ösztrogénmetabolitok kialakulásának sejtszintü bizonyítéka [58].

Hím Sprague-Dawley patkányokban prostatitis indukálását követően az E1-, E2-, 16-OHE1-, valamint 4-OHE2-szintek emelkedését tapasztalták [59]. Benignus $\mathrm{BPH}-1$ és malignus, PC-3 típusú humán prosztatasejtvonalakat leptinnel és E2-vel kezelve, emelkedett 4-OHEl- és/vagy csökkent 2-MeOE2-, 4-MeOE2-, valamint 2-MeOEl-szinteket találtak. Ezt erősítik valós idejű polimeráz láncreakció (RT-PCR) mérések eredményei. E mérések során a leptin serkentette az aromatáz és a CYPlBl enzimek termelődését, ugyanakkor gátolta a COMT expresszióját. Mindezek arra engednek következtetni, hogy az ösztrogénmetabolizmus játszik szerepet a leptin indukálta sejtproliferációban prosztatasejtekben [60]. Ezzel szemben Kosti és mtsai fordított korrelációt találtak a 16-KE2 és a 17-epiE3 aktivitása és a prosztatakarcinóma prevalenciája között. Nem találtak összefüggést, amikor a 16-KE2-t vagy a 17-epiE3-t külön-külön hasonlították a PSA-szintekhez, ugyanakkor a két metabolit együttes értékelésekor szignifikáns, szoros korrelációt mutattak ki [61] (1. táblázat).

\section{Az ösztrogénmetabolom szerepe tüdőtumorokban és COPD kialakulásában}

Tüdőben az ösztrogének szerepét eddig kevéssé tanulmányozták. A megjelent közlemények szerint - amelyek csupán két betegségben tesznek említést az ösztrogénmetabolomról - az ösztrogénreceptorok a tüdőtumorok akár 90\%-ában jelen vannak. Az ösztrogénreceptorokhoz kapcsolt folyamatok végbemenetele a genotoxikus 4-hidroxi-ösztrogének és 16-hidroxi-ösztrogének jelenlétét feltételezi, amelyeket a CYPIBI enzim állít elő. CYPIBI knock out egerek tüdejében drámai módon lecsökkent a 4-hidroxi-ösztradiol szintje, ugyanakkor a CYPlAl enzim expressziója jelentős mértékben megemelkedett. Az ER $\alpha$ és ER $\beta$ mellett GPER-t mutattak ki krónikus obstruktív tüdőbetegséggel diagnosztizált személyek tüdőszövetéből. A GPER lehet felelős a nem kanonikus ERmediált útvonal aktivitásáért. Emellett emelkedett 17ß-HSD1-, valamint aromatázaktivitást találtak, amelyek részt vesznek az aktív ösztrogének lokális szintézisében $[36,37]$.

\section{Az ösztrogénmetabolitok vizsgálati lehetőségei}

A keringő ösztrogének közvetlen kimutatását elsősorban immunoassay-módszerek (ELISA, radioimmunoassay) segítségével végzik. Általános vélekedéssé vált azonban, hogy ezek analitikai teljesítményjellemzői sok tekintetben elfogadhatatlanok. A kialakult álláspontot igazolja, hogy a College of American Pathologists által 2008-ban lebonyolított szteroid külső körvizsgálatban azonos immunoassay-módszerrel kapott E2-eredmények között kilencszeres eltérés volt [62]. Hsing és mtsai radioimmunoassay (RIA) és gázkromatográffal kapcsolt tömegspektrométerrel (GC-MS), illetve folyadékkromatográffal kapcsolt tandem tömegspektrométerrel (LC-MS/ MS) végzett vizsgálatok során kapott eredményeket hasonlítottak össze, és azt találták, hogy az ösztrogének

1. táblázat |Autoimmun betegségekben, tüdőbetegségekben, emlőrákban, prosztatabetegségekben és a vázrendszer betegségeiben vizsgált ösztrogénmetabolit vegyületek

\begin{tabular}{|c|c|c|c|c|c|}
\hline & \multicolumn{5}{|c|}{ Ösztrogén-metabolom asszociálta kórképek } \\
\hline & $\begin{array}{l}\text { Autoimmun } \\
\text { betegségek }\end{array}$ & Tüdőbetegségek & Emlőrák & $\begin{array}{l}\text { Prosztatát érintő } \\
\text { betegségek }\end{array}$ & $\begin{array}{l}\text { Csontrendszer } \\
\text { tumoros betegségei }\end{array}$ \\
\hline Vizsgált mátrixok & $\begin{array}{l}\text { Szérum, synovialis } \\
\text { folyadék, humán } \\
\text { monocyta-sejtvonal } \\
\text { (THPl) }\end{array}$ & Tüdőszövet & $\begin{array}{l}\text { Szérum, plazma, } \\
\text { vizelet, emlőszövet }\end{array}$ & $\begin{array}{l}\text { Szérum, } \\
\text { prosztataszövet }\end{array}$ & Csontszövet \\
\hline Vizsgált vegyületek & $\begin{array}{l}\text { 2-OHE1, 2-OHE2, } \\
\text { 4-OHE1, 4-OHE2, } \\
\text { 16-OHE1, 16-OHE2 }\end{array}$ & $\begin{array}{l}\text { 2-OHE1, 4-OHE1, } \\
\text { 4-OHE2, 2-MeOE1, } \\
\text { 2-MeOE2 }\end{array}$ & $\begin{array}{l}\text { E1, E2, E3, 2-OHE1, } \\
\text { 2-MeOE1, 2-OHE2, } \\
\text { 2-MeOE2, 3-MeOE1, } \\
\text { 4-OHE1, 4-MeOE1, } \\
\text { 4-MeOE2, 17-epiE3, } \\
\text { 16-ketoE2, 16-epiE3 }\end{array}$ & $\begin{array}{l}\text { E1, E2, E3, 2-OHE1, } \\
\text { 2-MeOE1, 2-OHE2, } \\
\text { 2-MeOE2, 3-MeOE1, } \\
\text { 4-OHE1, 4-MeOE1, } \\
\text { 4-MeOE2, 17-epiE3, } \\
\text { 16-ketoE2, 16-epiE3 }\end{array}$ & $\begin{array}{l}\text { 17 } \beta \text {-E2, 2-OHE1, } \\
\text { 4-OHE1, 16 } \alpha \text {-OHE1 }\end{array}$ \\
\hline
\end{tabular}


RIA-módszerrel kapott szintjei mintegy 50\%-kal voltak magasabbak [63]. Faupel-Badger és mtsai a vizelet ösztrogén- és ösztrogénmetabolit-tartalmát határozták meg RIA-, ELISA- és LC-MS/MS eljárásokkal [64].

A szteroidvegyületek meghatározásában évtizedek óta jelentős szerepet játszik a gázkromatográfiás elválasztáson alapuló mérés. A vizes közegü (így a klinikai) minták gázkromatográfiás vizsgálata azonban bonyolult mintaelőkészítést igényel. Az elmúlt 15 évben ezért a klinikai laboratóriumok eszköztárában az egyes teljesítményjellemzőket és az áteresztőképességet tekintve gyakran előnyösebb, emellett egyszerübb minta-előkészítést igénylő folyadékkromatográffal kapcsolt tandem tömegspektrométer (LC-MS/MS) vált elterjedtebbé. A szisztémás E1- és E2-vizsgálatok fó tapasztalatait Kushnir és mtsai foglalták össze [65].

Az E1 és E2 teljes metabolitprofiljának szérumban történő vizsgálatára Fubrman és mtsai dolgoztak ki eljárást. Egészséges egyénekben legnagyobb mennyiségben a 16-hidroxilációs út termékeit (elsősorban az ösztriol konjugált formáját) mutatták ki, amit a 2-hidroxi-származékok (elsősorban a 2-hidroxi-ösztron), végül a 4-hidroxi-származékok (fóleg a 4-hidroxi-ösztron) követtek [66]. A metabolitprofil vizsgálatára vizeletból is hasonló vizsgálati módszert fejlesztettek ki, amely hasonló képet mutatott [67]. Egyelőre nem közöltek eljárást az ösztrogénmetabolom perifériás terekben történó vizsgálatához, jelen tanulmány szerzői azonban jelenleg ennek kifejlesztésén dolgoznak.

\section{Következtetések}

Az ösztrogének a perifériás szövetekben és vízterekben lokálisan keletkeznek, ott fejtik ki hatásukat és metabolizálódnak. A szisztémás koncentrációk a szöveti viszonyokat nem tükrözik. Az ösztrogénhormonok mellett metabolitjaik is szerepet játszanak több malignus és autoimmun folyamat keletkezésében és progressziójában. Az ösztrogénhormonokkal összefüggést mutató kórállapotokban a nem és - nóknél - az életkor sok esetben meghatározó. Az ösztrogénmetabolom diagnosztikailag hasznos vizsgálatához olyan eljárásokra van szükség, amelyek lehetővé teszik e vegyületek egymás mellett történő, nagy érzékenységü meghatározását a szérumban és a perifériás szövetekben, vízterekben. Gyógyszerek, természetes eredetű élelmiszerek és természetgyógyászati készítmények, táplálékkiegészítők fitoösztrogén- és CYP-modulátortartalma az ösztrogénvegyületek élettani és kórélettani múködésébe szisztémásan és perifériásan egyaránt beavatkozhatnak. A fentiek igazolják, hogy az ösztrogénvegyületek klinikai jelentősége a klasszikus hormonális hatásokon messze túlmutat. E vegyületek további vizsgálata számos kórképben eredményezhet a korai diagnózis és az egyénre szabott terápiák szempontjából jelentős előrelépést. A perspektívák és a vizsgálatokkal kapcsolatos kihívások ezt a területet kiemelkedően érdekessé teszik a kutatóorvosok és a klinikum számára egyaránt.
Anyagi támogatás: A közlemény megírása anyagi támogatásban nem részesült.

Szerzői munkamegosztás: A szerzők egyenlő arányban és mértékben vettek részt az irodalomkutatásban és a közlemény megírásában. A cikk végleges változatát valamennyi szerző elolvasta és jóváhagyta.

Érdekeltségek: A szerzőknek nincsenek érdekeltségeik.

\section{Irodalom}

[1] Lee AJ, Cai MX, Thomas PE, et al. Characterization of the oxidative metabolites of 17 beta-estradiol and estrone formed by 15 selectively expressed human cytochrome P450 isoforms. Endocrinology 2003; 144: 3382-3398.

[2] Tsuchiya Y, Nakajima M, Yokoi T. Cytochrome P450-mediated metabolism of estrogens and its regulation in human. Cancer Lett. 2005; 227: 115-124.

[3] Simpson ER. Sources of estrogen and their importance. J Steroid Biochem Mol Biol. 2003; 86: 225-230.

[4] Vásárhelyi B, Mészáros K, Karvaly G, et al. Focusing on tissue biomarkers. Estrogens as key players in the modulation of immune response and autoimmunity. [Fókuszban a szöveti biomarkerek. Az ösztrogének mint a szövetspecifikus immunválasz és autoimmunitás modulálásának kulcsszereplői.] Orv Hetil. 2015; 156: 2070-2076. [Hungarian]

[5] Geisler J. Breast cancer tissue estrogens and their manipulation with aromatase inhibitors and inactivators. J Steroid Biochem Mol Biol. 2003; 86: 245-253.

[6] Muir M, Romalo G, Wolf L, et al. Estrone sulfate is a major source of local estrogen formation in human bone. J Clin Endocrinol Metab. 2004; 89: 4685-4692.

[7] Barakat R, Oakley O, Kim H, et al. Extra-gonadal sites of estrogen biosynthesis and function. BMP Rep. 2016; 49: 488-496.

[8] Stocco C. Tissue physiology and pathology of aromatase. Steroids 2012; 77: 27-35.

[9] Sasano H, Suzuki T, Nakata T, et al. New development in intracrinology of breast carcinoma. Breast Cancer 2006; 13: 129136.

[10] Falk RT, Xu X, Keefer L, et al. A liquid chromatography-mass spectrometry method for the simultaneous measurement of fifteen urinary estrogens and estrogen metabolites: assay reproducibility and inter-individual variability. Cancer Epidemiol Biomarkers Prev. 2008; 17: 3411-3418.

[11] Hong CC, Tang BK, Hammond GL, et al. Cyctochrome P450 1A2 (CYP1A2) activity and risk factors for breast cancer: a crosssectional study. Breast Cancer Res. 2004; 6: 352-365.

[12] Raftogianis R, Creveling C, Weinshilboum R, et al. Estrogen metabolism by conjugation. J Natl Cancer Inst Monogr. 2000; 27 : 113-124.

[13] Dawling S, Roodi N, Mernaugh RL, et al. Catechol-O-methyltransferase (COMT)-mediated metabolism of catechol estrogens: comparison of wild-type and variant COMT isoforms. Cancer Res. 2001; 61: 6716-6722.

[14] Jansson A, Gunnarsson C, Stal O. Proliferative responses to altered 17beta-hydroxysteroid dehydrogenase (17HSD) type 2 expression in human breast cancer cells are dependent on endogenous expression of 17HSD type 1 and the oestradiol receptors. Endocr Relat Cancer 2006; 13: 875-884.

[15] Cui J, Shen Y, Li R. Estrogen synthesis and signaling pathways during ageing: from periphery to brain. Trends Mol Med. 2013; 19: 197-209.

[16] Azcoitia I, Yague JG, Garcia-Segura LM. Estradiol synthesis within the human brain. Neuroscience 2011; 191: 139-147.

[17] Zanger UM, Schwab M. Cytochrome P450 enzymes in drug metabolism: regulation of gene expression, enzyme activities, 
and impact of genetic variation. Pharm Ther. 2013; 138: 103141.

[18] Sterling KM Jr, Cutroneo KR. Constitutive and inducible expression of cytochromes P4501A (CYPlAl and CYPlA2) in normal prostate and prostate cancer cells. J Cell Biochem. 2004; 91 : 423-429.

[19] Yager JD, Davidson NE. Estrogen carcinogenesis in breast cancer. N Engl J Med. 2006; 354: 270-282.

[20] Liu J, Sridhar J, Foroozesh M. Cytochrome P450 family 1 inhibitors and structure-activity relationships. Molecules 2013; 18 : 14470-14495.

[21] Bruno RD, Njar VC. Targeting cytochrome P450 enzimes: a new approach in anti-cancer drug development. Bioorg Med Chem. 2007; 15: 5047-5060.

[22] Zhang CZ, Wang SX, Zhang Y, et al. In vitro estrogenic activities of Chinese medicinal plants traditionally used for the management of menopausal symptoms. J Etnopharmacol. 2005; 98 : 295-300.

[23] Dave H, Ledwani L. A review on anthraquinones isolated from Cassia species and their applications. Indian J Nat Prod Resources 2012; 3: 291-319.

[24] Yager JD. Mechanisms of estrogen carcinogenesis: The role of E2/E1-quinone metabolites suggests new approaches to preventive intervention - a review. Steroids 2015, 99(Pt A): 56-60.

[25] An KC. Selective estrogen receptor modulators. Asian Spine J. 2016; 10: 787-791

[26] Zhu BT, Conney AH. Functional role of estrogen metabolism in target cells: review and perspectives. Carcinogenesis 1998; 19: $1-27$.

[27] Zhu BT, Han GZ, Shim JY, et al. Quantitative structure-activity relationship of various endogenous estrogen metabolites for human estrogen receptor alpha and beta subtypes: insights into the structural determinants favoring a differential subtype binding. Endocrinology 2006; 147: 4132-4150.

[28] Simpson E, Rubin G, Clyne C, et al. Local estrogen biosynthesis in males and females. Endocr Relat Cancer 1999; 6: 131-137.

[29] Liehr JG, Ricci MJ. 4-hydroxylation of estrogens as marker of human mammary tumors. Proc Natl Acad Sci USA. 1996; 93 3294-3296.

[30] Zahid M, Saeed M, Lu F, et al. Inhibition of catechol-O-methyl transferase increases estrogen-DNA adduct formation. Free Rad ic Biol Med. 2007; 43: 1534-1540.

[31] Lábas A, Krámos B, Oláh J. Combined docking and quantum chemical study on CYP-mediated metabolism of estrogens in man. Chem Res Toxicol. 2017; 30: 583-594.

[32] Sowers MR, McConnell D, Jannausch M, et al. Estradiol and its metabolites and their association with knee osteoarthritis. Arthritis Rheumatism 2006; 54: 2481-2487.

[33] Cutolo M, Brizzolara R, Atzeni F, et al. The immunomodulatory effects of estrogens: clinical relevance in immun-mediated rheumatic disseases. Ann NY Acad Sci. 2010, 1193: 36-42.

[34] Savolainen-Peltonen H, Vihma V, Leidenius M, et al. Breast adipose tissue estrogen metabolism in postmenopausal women with or without breast cancer. J Clin Endocrinol Metab. 2014; 99: E2661-E2667.

[35] Fuhrman BJ, Schairer C, Gail MH, et al. Estrogen metabolism and risk of breast cancer in postmenopausal women. J Natl Cancer Inst. 2012; 104: 326-339.

[36] Tam A, Morrish D, Wadsworth S, et al. The role of female hormones on lung function in chronic lung diseases. BMC Womens Health $2011 ; 24: 2-9$.

[37] Peng J, Xu X, Mace BE, et al. Estrogen metabolism within the lung and its modulation by tobacco smoke. Carcinogenesis 2013; 34: 909-915

[38] Solum EJ, Akselsen ØW, Vik A, et al. Synthesis and pharmacological effects of the anti-cancer agent 2 -methoxyestradiol. Curr Pharm Des. 2015; 21: 5453-5466.
[39] Chatterton RT Jr, Geiger AS, Gann PH, et al. Formation of es trone and estradiol from estrone sulfate by normal breast parenchymal tissue. J Steroid Biochem Mol Biol. 2003; 86: 159-166.

[40] Falk RT, Brinton LA, Dorgan JF, et al. Relationship of serum estrogens and estrogen metabolites to postmenopausal breast cancer risk: a nested case-control study. Breast Cancer Res. 2013; 15: R34.

[41] Westerlind KC, Gibson KJ, Evans GL, et al. The catechol estrogen, 4-hydroxyestrone, has tissue-specific estrogen actions. J Endocrinol. 2000; 167: 281-287.

[42] Eliassen AH, Missmer SA, Tworoger SS, et al. Circulating 2-hydroxy and 16alpha-hydroxy estrone levels and risk of breast cancer among postmenopausal women. Cancer Epidemiol Biomarkers Prev. 2008; 17: 2029-2035.

[43] Eliassen AH, Ziegler RG, Rosner B, et al. Reproducibility of fifteen urinary estrogens and estrogen metabolites over a 2- to 3 -year period in premenopausal women. Cancer Epidemiol Biomarkers Prev. 2009; 18: 2860-2868.

[44] Weidler C, Harle P, Schedel J, et al. Patients with rheumatoid arthritis and systemic lupus erythematosus have increased renal excretion of mitogenic estrogens in relation to endogenous antiestrogens. J Rheumatol. 2004; 31: 489-494.

[45] Ngo, ST, Steyn FJ, McCombe PA. Gender differences in autoimmune disease. Front Neuroendocrinol. 2014; 35: 347-369.

[46] Schmidt M, Weidler C, Naumann H, et al. Androgen conversion in osteoarthritis and rheumatoid arthritis synoviocytes - androstenedione and testosterone inhibit estrogen formation and favor production of more potent 5 -alpha-reduced androgens. Arthritis Res Ther. 2005; 7: R938-R948.

[47] Cutolo M, Sulli A, Capellino S, et al. Sex hormones influence on the immune system: basic and clinical aspects in autoimmunity. Lupus 2004; 13: 635-638.

[48] Schmidt M, Hartung R, Capellino S, et al. Estrone/17beta-estradiol conversion to, and tumor necrosis factor inhibition by, estrogen metabolites in synovial cells of patients with rheumatoid arthritis and patients with osteoarthritis. Arthritis Rheum. 2009; 60: 2913-2922.

[49] Capellino S, Montagna P, Villaggio B, et al. Hydroxylated estrogen metabolites influence the proliferation of cultured human monocytes: possible role in synovial tissue hyperplasia. Clin Exp Rheumatol. 2008; 26: 903-909.

[50] Capellino S, Straub RH, Cutolo M. Aromatase and regulation of the estrogen-to-androgen ratio in synovial tissue inflammation: common pathway in both sexes. Ann NY Acad Sci. 2014; 1317: 24-31.

[51] Khan D, Ansar Ahmed S. The immune system is a natural target for estrogen action: opposing effects of estrogen in two prototypical autoimmune diseases. Front Immunol. 2015; 6: 635.

[52] Swaneck GE, Fishman J. Covalent binding of the endogenous estrogen 16alpha-hydroxyestrone to estradiol receptor in human breast cancer cells: characterization and intranuclear localization. Proc Natl Acad Sci USA. 1988; 85: 7831-7835.

[53] Pellino G, Sciaudone G, Patturelli M, et al. Relatives of Crohn's disease patients and breast cancer: an overlooked condition. Int J Surg. 2014; 12(Suppl 1): 156-158.

[54] Tian G, Liang JN, Wang ZY, et al. Breast cancer risk in rheumatoid arthritis: an update meta-analysis. BioMed Res Int. 2014; 2014: 453012

[55] Nielsen NM, Rostgaard K, Rasmussen S, et al. Cancer risk among patients with multiple sclerosis: a population-based register study. Int J Cancer 2006; 118: 979-984.

[56] Michaud JE, Billups KL, Partin AW. Testosterone and prostate cancer: an evidence-based review of pathogenesis and oncologic risk. Ther Adv Urol. 2015; 7: 378-387.

[57] Moon JY, Choi MH, Kim J. Metabolic profiling of cholesterol and sex steroid hormones to monitor urological diseases. Endocr Relat Cancer 2016, 23: R455-R467. 
[58] Ellem SJ, Risbridger GP. Aromatase and prostate cancer. Minerva Endocrinol. 2006; 31: 1-12.

[59] Mosli HA, Al-Abd AM, El-Shaer MA, et al. Local inflammation influences oestrogen metabolism in prostatic tissue. BJU Int. 2012, 110: 274-282.

[60] Habib CN, Al-Abd AM, Tolba MF, et al. Leptin influences estrogen metabolism and accelerates prostate cell proliferation. Life Sci. 2015 ; 121 : 10-15

[61] Kosti O, Xu X, Veenstra TD, et al. Urinary estrogen metabolites and prostate cancer risk: a pilot study. Prostate 2011; 71: 507516.

[62] Soldin SJ, Soldin OP. Steroid hormone analysis by tandem mass spectrometry. Clin Chem. 2009; 55: 1061-1066.

[63] Hsing AW, Stanczyk FZ, Bélanger A, et al. Reproducibility of serum sex steroid assays in men by RIA and mass spectrometry. Cancer Epidemiol Biomarkers Prev. 2007; 16: 1004-1008.

[64] Faupel-Badger JM, Fuhrman BJ, Xu X, et al. Comparison of liquid chromatography-mass spectrometry, radioimmunoassay, and enzyme-linked immunosorbent assay methods for measurement of urinary estrogens. Cancer Epidemiol Biomarkers Prev. 2010; 19: $292-300$.
[65] Kushnir MM, Rockwood AL, Roberts WL, et al. Liquid chromatography-tandem mass spectrometry for analysis of steroids in clinical laboratories. Clin Biochem. 2011; 44: 77-88.

[66] Fuhrman BJ, Xu X, Falk RT, et al. Assay reproducibility and interindividual variation for 15 serum estrogens and estrogen metabolites measured by liquid chromatography-tandem mass spectrometry. Cancer Epidemiol Biomarkers Prev. 2014, 23: 2649-2657.

[67] Falk RT, Xu X, Keefer L, et al. A liquid chromatography-mass spectrometry method for the simultaneous measurement of fifteen urinary estrogens and estrogen metabolites: assay reproducibility and inter-individual variability. Cancer Epidemiol Biomarkers Prev. 2008; 17: 3411-3418.

(Kovács Krisztián, Budapest, Nagyvárad tér 4., 1089 e-mail: kovacs.krisztianl@med.semmelweis-univ.hu)

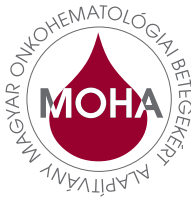

A Magyar Onkohematológiai Betegekért Alapítvány (MOHA) közhasznú civil szervezet, mely azért jött létre, hogy segítse a vérképzöszervi betegségekkel kïzdő érintettek hiteles tájékoztatását, érzelmi támogatást nyújtson számukra és képviselje érdekeiket a mindenkori döntéshozók elött.

\section{BETEGEDUKÁCIÓ}

A hematológiai betegségekkel és korszerú kezelési lehetôségekkel kapcsolatos általános, közérthető tájékoztatásban segítjük az érintetteket a legkiválóbb szakemberek bevonásával. Kifejezett célunk a bizonyítékokon alapuló orvoslás iránti bizalom megerósítése és a természettudományos gondolkodás népszerúsítése.

\section{PSZICHOSZOCIÁLIS TÁMOGATÁS}

Támogató csoportjaink célja - az ismeretterjesztésen túl a hasonló problémával küzdő betegek és családtagjaik összefogása, érzelmi támogatása, a bizalmon alapuló orvosbeteg kapcsolat erősítése. A csoporton belül lehetőség van találkozni olyan sorstársakkal, akiknek a példája segítséget nyújthat a sikeres megküzdéshez, a velük való őszinte beszélgetés oldhatja a betegség és a kezelések miatt érzett szorongást.

\section{ÉRDEKÉRVÉNYESÍTÉS}

A MOHA célja, hogy minden érintett megkapja a betegségére ajánlott legkorszerúbb kezelést. Míg az egyes betegek kevéssé tudnak hatékonyan fellépni érdekeik védelmében, addig összefogással, civil nyomásgyakorlással sikert érhetünk el. Az orvostudomány fejlődésének köszönhetốen folyamatosan jelennek meg az új terápiák, amelyek további esélyt adnak a betegeknek. Fontos, hogy az érintettek tudjanak az új lehetôségekről és konzultáljanak arról kezelőorvosukkal! Célunk, hogy a betegek a szükséges gyógyszerekhez minél egyszerúbben, kiszámíthatóan és átláthatóan juthassanak hozzá a megfelelő időben, ezért elvárásunk, hogy az európai gyakorlathoz hasonlóan a betegekkel kapcsolatos döntéshozói folyamatokba vonják be a betegszervezetek képviselőit is.

\section{ELÉRHETŐSÉGEINK}

Magyar Onkohematológiai Betegekért Alapítvány moha@onkohemat.hu, +36 204398645 www.onkohemat.hu, www.facebook.com/onkohemat.hu

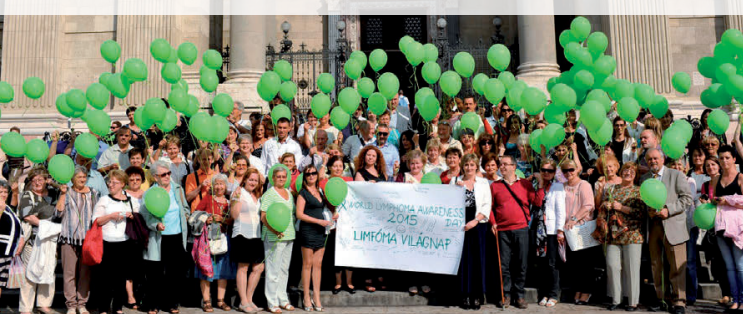

